\title{
The Development of Reading Materials in School Literacy Movements for Senior High School Students Based on Local Culture of Karo
}

\author{
Yoana Stephani Tarigan', Biner Ambarita ${ }^{2}$, Mutsyuhito Solin ${ }^{2}$ \\ ${ }^{I}$ Master Student in State University of Medan (Unimed), Indonesia \\ ${ }^{2}$ Lecturer in in State University of Medan (Unimed), Indonesia \\ Yoanastephani1@gmail.com
}

\begin{abstract}
Literacy has the meaning and implications of basic reading and writing skills to acquire and manipulate knowledge through written texts, from metalinguistic analysis of grammatical units to the structure of oral and written texts. This study deals with the development of reading materials in school literacy movements for senior high school students based on local culture of Karo. The type of this study is development study that is the development of short story text reading materials based on character education as an ingredient in the school literacy movement. This development study refers to the development theory proposed by Borg and Gall. The conclusion of this study is the feasibility of reading material in the school literacy movement for senior high school students based on local culture of Karo is eligible and suitable to be used as reading material, based on the assessment of material experts, and design experts. The results of the assessment based on the responses of teachers and students in the Senior High School 1 of Berastagi concluded that reading material in the school literacy movement for senior high school students based on local culture of Karo had been found to be effective because it met the needs and overall criteria "very good".
\end{abstract}

Keywords : development of reading; school literacy; local culture

\section{Introduction}

Reading is one aspect of language skills which is important in the development of one's knowledge in learning and everyday life. Many reading material is a source of information such as books, newspapers, magazines, tabloids that can be easily obtained by students and the public. However, the ability of a reader determines how much information they receives.

The results of a recent study conducted by PISA (2015) that Indonesian students' reading comprehension was still relatively low. PISA shows Indonesia is ranked 64th out of 72 participating countries (OECD, 2017). From these results it can be concluded that the practice of education carried out in schools has not shown the function of the school as a learning organization that seeks to make all citizens become skilled at reading to support school citizens as lifelong learners.

Regarding reading, the initial problem was based on interviews conducted with the teacher of the Indonesian Language Study at Senior High School 1 Berastagi (March 11, 2017), which stated that not all students care about making personal reading lists and filling in class reading lists. The reading list is intended to function to share advice and find friends whose reading preferences are the same. This type of record helps to identify certain groups and activities, as well as enliven the class taught, which in turn can help increase students' interest in reading.

Turmiati (2018) in her research entitled "Differences in the Ability to Read and Write Students in KTSP 'Schools and with K13" revealed the main problem in reading learning in schools today is reading learning is still carried out carelessly. Bad habits can be seen from the 
fact that reading learning is rarely done to encourage students to have the right speed and reading style.

\section{Review of Literatures}

\subsection{Reading Materials}

Many opinions regarding the understanding of reading material and library materials. Each understanding has its own perspective. These two terms consist of 2 syllables, namely material and reading, as well as materials and literature. In the Large Dictionary of Indonesian Language Material means everything that can be used or needed for a particular purpose. While reading has the meaning of books etc. read. While the library has the meaning of the book. In other words reading material is all printed media provided to the public in the form of books, magazines, tabloits, newspapers, brochures, leaflets, and other informative printed materials that can be read, studied and provide benefits to people's lives. Whereas Yulia (2009: 1.7) alludes to the fact that the world of education requires reading material or other material for intellectual recreational purposes and other reading material that enriches the user's domain.

Dahlan (2013: 24) describes reading material for studies in general are materials in the form of nonfiction consisting of various types. However, it is certain that fiction is also used as a reading material if the discipline in question is literature. Reading material for pleasure in general are materials in the form of fiction, light articles, newspapers, and others. Furthermore, reading material has readability criteria. Dahlan (2013: 24) states that readability is the suitability of reading for certain readers. Interesting reading material is a material that is close to the lives of students, is being discussed in the community and is useful. In addition, reading materials are based on consideration of various values (such as content, benefits, education, morals, aesthetics, ethics, etc.).

\subsection{Literacy}

Literacy is the basis for lifelong learning activities. This is very important for social and human development in order to increase the ability to be able to change lives in a better direction. Initially literacy was only interpreted as literacy. But this is a wrong perception. Interpreting literacy as literacy can result in literacy anomalies. Where literacy is meant only revolves around literal and technical literacy. Not culturally and deeply. Therefore literacy is more suitable to be interpreted as literacy. As it is said by Irkham dalam (Gong, 2012) that literacy is literacy.

So literacy has the meaning and implications of basic reading and writing skills to acquire and manipulate knowledge through written texts, from metalinguistic analysis of grammatical units to the structure of oral and written texts, from the impact of human history to the philosophical and social consequences of western education. Even changes in human evolution are the effects of literacy thinking.

\subsection{Local Wisdom}

Local wisdom is formed as a cultural superiority of the local community as well as geographical conditions in a broad sense. Local wisdom is a product of the past culture that should be continuously taken into account in life.

Ridwan (2007: 28) in his research entitled "Local Wisdom Scientific Platform" states that local wisdom or often called local wisdom can be understood as a human effort by using his 
mind (cognition) to act and behave towards something, object, or event that occurs in certain spaces. The above definition is arranged etymologically, wisdom is understood as a person's ability to use his mind in acting and acting as a result of an assessment of something, object, or event that occurs. As a term wisdom is often interpreted as 'wisdom'. Local spatially refers to limited interaction space with a limited value system.

\section{Research Methods}

This research was conducted at Senior High School 1 Berastagi in class X students. The reason for choosing this school was that there had never been any research on the same problem. The type of this research is development research that is the development of short story text reading materials based on character education as an ingredient in the school literacy movement. This development study refers to the development theory proposed by Borg and Gall.

\section{Discussion}

The process of developing reading material in the school literacy movement for high school students based on the local culture of Karo was carried out in several stages namely preliminary study, initial product development and product testing.

\subsection{Stage I Preliminary Study}

The needs analysis in the development research began by distributing a questionnaire of needs analysis to 32 class X students and 2 Indonesian language teachers in Senior High School 1 Berastagi on reading material in the school literacy movement for high school students based on the local culture of Karo. The search results from the questionnaire aims to make the reading material developed in accordance with the needs of Senior High School 1 Berastagi students.

Data obtained from the analysis of needs by teachers and students obtained the following conclusions.

1. A total of $71.87 \%$ of students from 32 students rarely knew the type of tradition in Batang district (found in the Karo area), $56.25 \%$ of students stated that they did not know the Karo tradition because they were not introduced by parents, $93.75 \%$ of students thought that tradition is one of the cultural heritages that needs to be maintained, $90.63 \%$ said that they needed reading books on culture, $62.5 \%$ needed readings that contained moral lessons to instill cultural values, $90.63 \%$ hoped that reading materials that would be developed would be useful for learning materials, and student needs related to the presentation or design of reading material.

2. As many as $100 \%$ of teachers from two Indonesian language teachers thought that children still rarely knew the culture in their area, 50\% said that children did not know their culture because they were not introduced by parents and $50 \%$ stated because of a lack of interest in children, $100 \%$ The teacher states that tradition is one of the cultural heritages that needs to be maintained, $100 \%$ of teachers need a reading book on tradition, $50 \%$ of teachers want reading material that has moral lessons to instill cultural values in children and 50\% want reading material that has elements knowledge, as many as $100 \%$ of teachers hope that reading materials that are useful 
for cultural / traditional learning materials, and the needs of teachers related to the physical reading material or the design of reading material.

\subsection{Stage II Initial Product Development}

The initial product development was carried out first by designing contents in the local Karo-based reading material for the school literacy movement. The content of reading material is some of the local customs / traditions of Karo. Some of the local cultures of Karo contain information related to Karo Culture, starting from the stages of the cultural walk and the purpose of the culture.

The development of the initial product of reading material based on the local culture of Karo as an ingredient in the school literacy movement began with the cover of reading material, information regarding Karo scripts, and some information regarding Karo local culture.

The cover is designed according to the conditions of the Karo Land which is famous for its natural fertility. The color and design of the cover is adapted to the natural fertility depicted by a beautiful forest. Karo traditional house is also displayed on the cover. This illustrates that the reading material developed is based on the local culture of Tanah Karo, so students are interested in reading information about their own culture. The cover also contains the role of the product developed which reads "School Literacy Movement Based on Karo Culture". This means that the product developed acts as a school literacy movement that contains the cultural content of Tanah Karo. The back cover of the reading material has the same color and style as the front cover. The front and back cover images can be seen below.

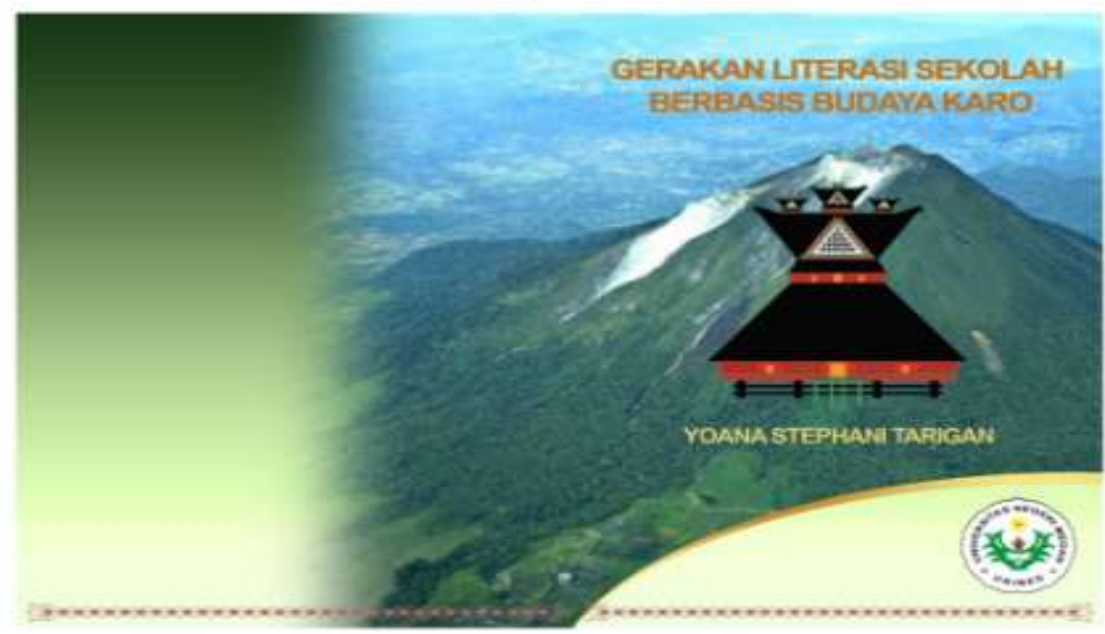

Figure 1. Cover of Reading Material

The initial part of the reading material based on the local culture of Karo as a material for the school literacy movement contains Karo characters, commonly referred to as "Indung Surat (main letter)". Parent Letters consist of twenty two letters with twenty two different sounds. More details on the picture can be seen below. 


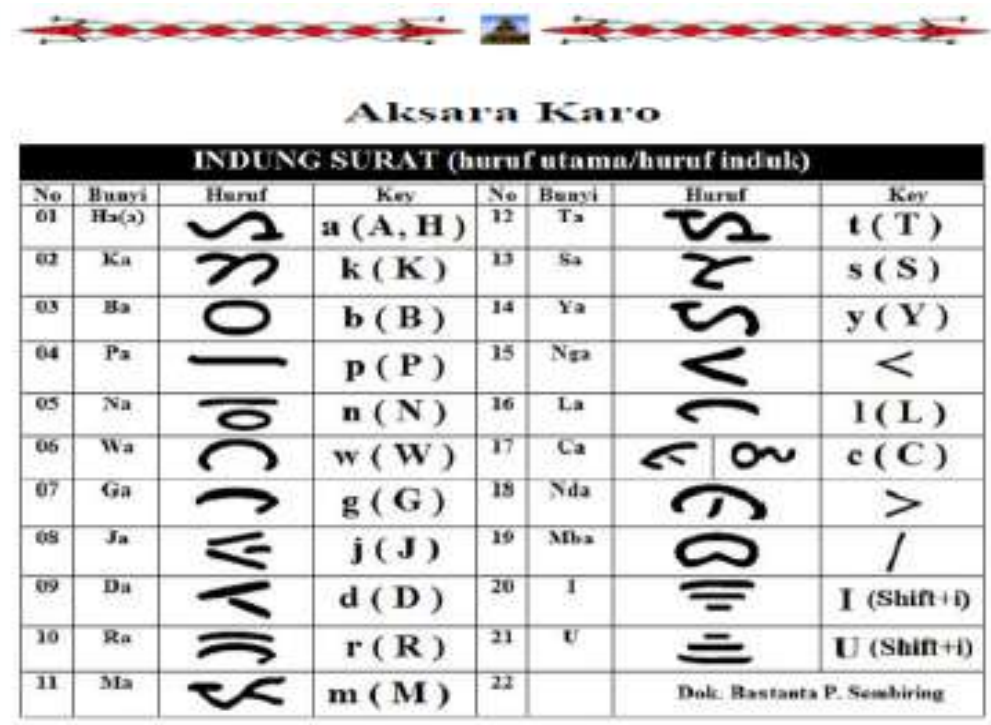

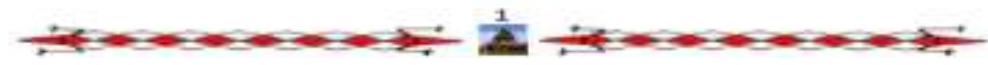

Figure 2. Initial Section of Reading Material (Karo Script)

Part of the contents of the local culture-based reading material of Karo as a material for the school literacy movement includes some of the local cultural content of Karo. Local culture contained in reading material can be in the form of information about culture or a stage of the running of a custom / tradition in Karo. One of the content on reading material that is information about Karo culture can be seen in the picture below.
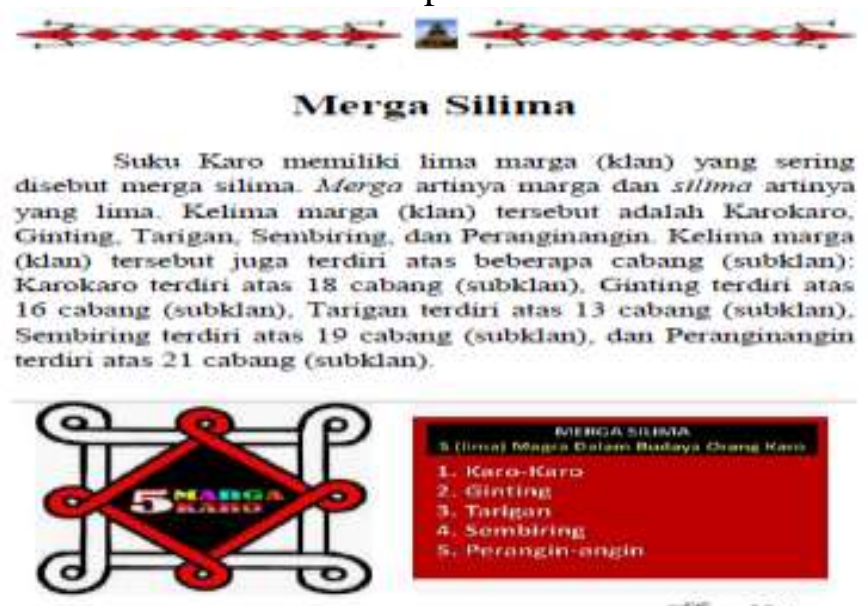

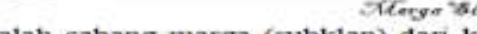
marga (klan) stuku Karo dan persebarannya.

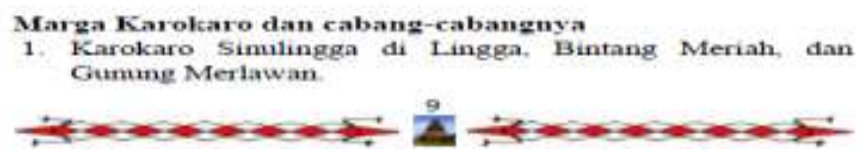

Figure 3. Karo Merge Silima Culture

The image is one of the contents of the reading material developed. Karo cultural information about Merge Silima on reading material is only to inform the reader about the 
origin of Merge Silima and the coverage that comes from the Merge Silima in detail. More details can be seen in the picture below.

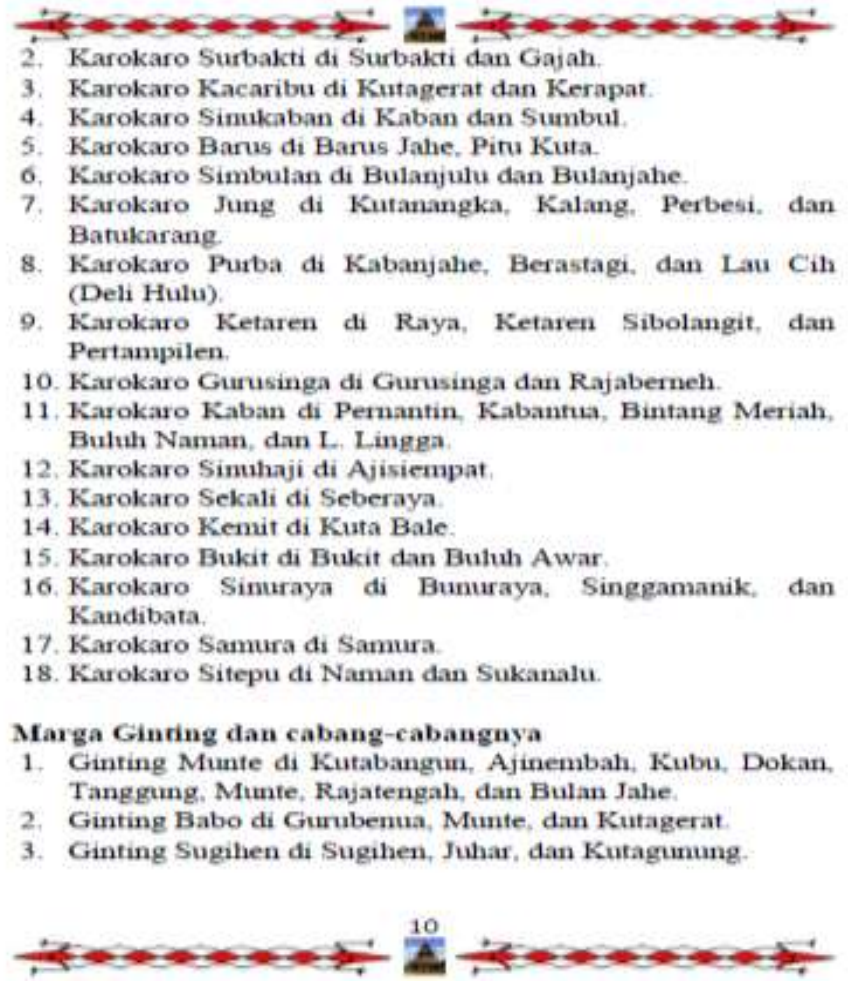

Figure 4. Karo Cultural Information Merge Silima in Detailed

Local culture contained in reading material in the form of information about a custom / tradition in the other Karo is "Unpacking the Use of Belo by Karo Society". One of the contents of the informational reading material about the use of Belo by the Karo community can be seen in the picture below.

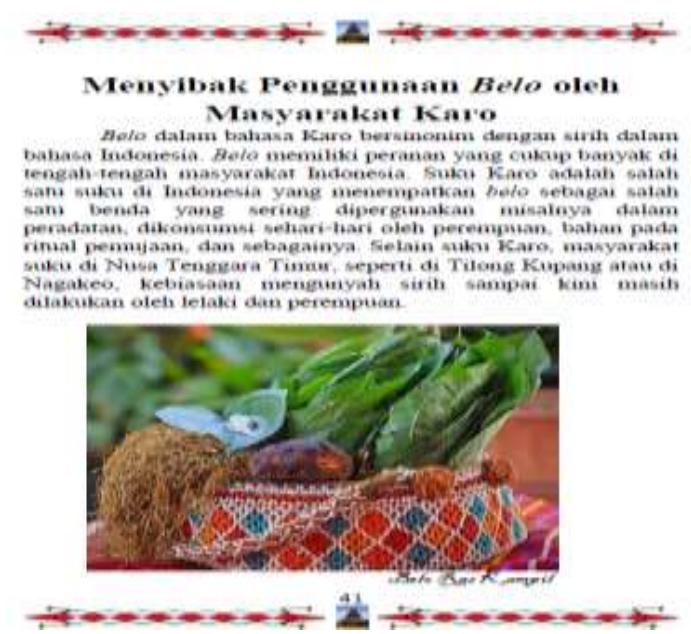

Figure 5. Karo Culture Unleashes the Use of Belo

The local culture contained in the reading material in the form of a stage in which a custom / tradition runs in Karo, one of which is the "Customary Marriage of the Karo Community". Customary marriage is first explained before arriving at the explanation of the 
marriage stages of the Karo community. The appearance of this tradition can be seen in the picture below.

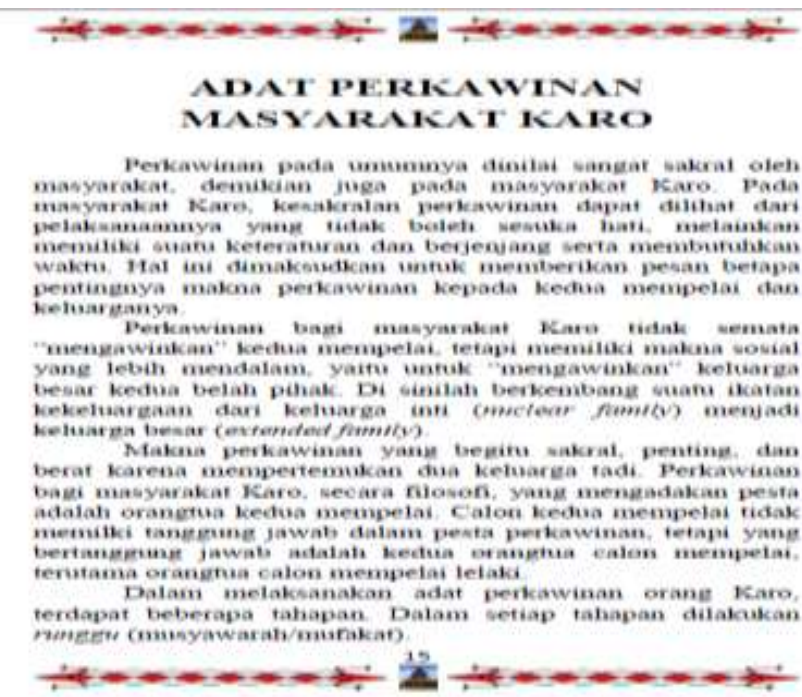

Figure 6. Indigenous Karo Culture of the Karo Community

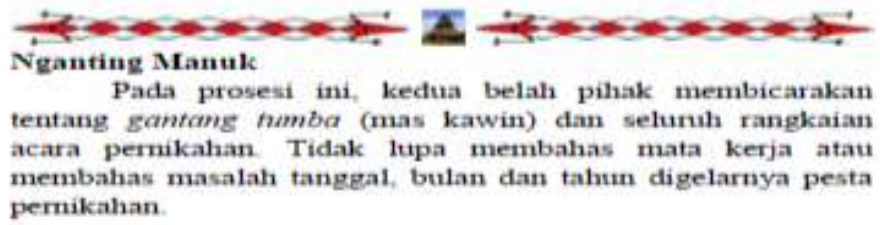

Lèja Ada

Hari ifu semua sangkep geluh (keluarga dekat) dari kedua belah pihak hadir untuk memuliakan pesta perkawinan itu. Pada masyarakat Karo, dikenal tiga kategori jenis pesta adat, yakni kerja sintua, kerja sintengah, dan kerja singuda. Penamaan jenis pesta peradatan ini dilihat dari berbagai sisi. Sisi pertama adalah besarnya batang un/uken (mahar). Kerja sintua, mahar tertinggi sebesar $R_{p} 866.000$. untuk kerja sintengah mahar sedang sebesar $\mathrm{Rp}_{\mathrm{p}} 666.000$, dan untuk kerja singuda maka mahar terendah adalah sebesar Rp 466.000.

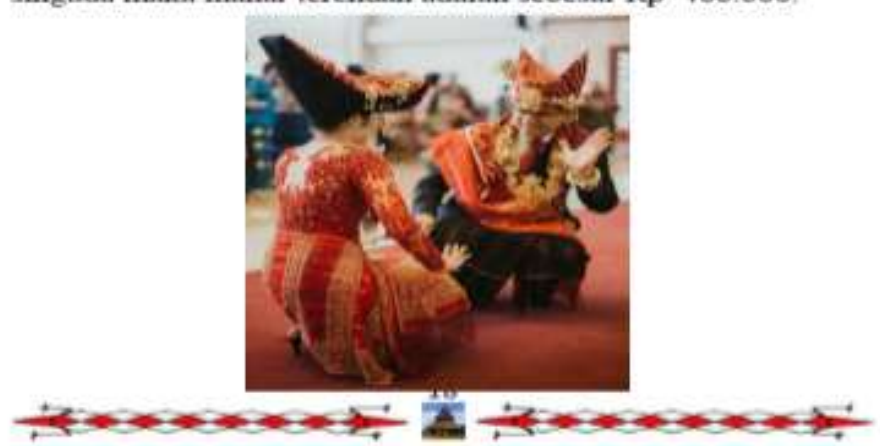

Figure 7. Procedures for Marriage of the Karo Community

The reading material based on the local culture of Karo as a material for the school literacy movement developed contains eleven local cultural contents of Karo which are explicitly presented on reading material. The titles of the cultures contained in the reading material developed are as follows.

\section{Aksara Karo}




\section{Pesona Kabupaten Karo}

3. Merge Silima

4. Adat Perkawinan Masyarakat Karo

5. Njungi Beras Piher

6. Pur-pur Sage

7. Menyibak Penggunaan Belo oleh Masyarakat Karo

8. Aron: Budaya Gotong Royong Masyarakat Karo

9. Gendang Guro-Guro Aron

10. Rumah Adat Karo

11. Kiras Bangun: Pahlawan dari Karo

All traditional content in the local Karo-based literature as material for the school literacy movement was closed with a column of opinions and experiences according to the reading. Next, there is a teacher / literacy team evaluation column. The appearance of the opinion column on the reading material can be seen in the picture below.
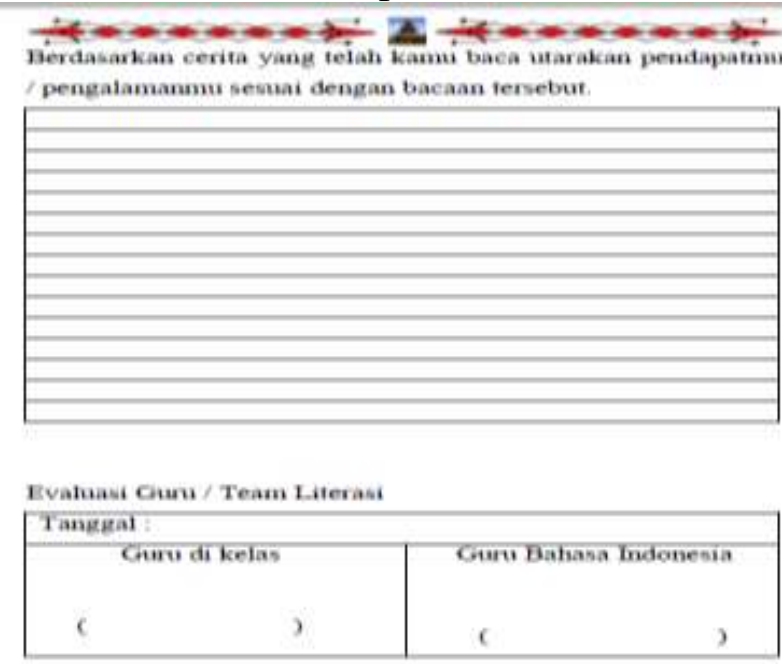

\section{Figure 8. Opinion Column and Teacher Evaluation / Literacy Team Column}

The thing that was done after designing the local culture-based reading material for Karo as a material for the school literacy movement was to carry out product validation by material experts, and design experts. The final step is to assess the teacher and students of the local culture-based reading material of Karo as an ingredient in the school literacy movement. This assessment was conducted by two Indonesian language teachers in Senior High School 1 Berastagi and 32 students at the school.

The product testing phase was carried out three times, namely individual trials (3 students), small group trials (9 students) and limited field trials (32 students). Individual trials obtain an average score of $76 \%$ with good criteria. Small group trials obtained an average value of $83.33 \%$ with very good criteria. Furthermore, limited field trials obtain an average value of $89.84 \%$ with very good criteria. 


\subsection{Feasibility of Reading Materials Based on the Local Culture of Karo}

The feasibility of reading material in the school literacy movement for high school students based on the local culture of Karo was obtained from the results of validation and assessment provided by material experts and design experts. Each expert consists of two people and in each aspect of the overall assessment is determined by the average score of the assessment criteria of each expert. Through the results of the assessment, it was then analyzed to determine the feasibility of reading material in the school literacy movement for high school students based on the local culture of Karo to be tested on students. After that, the product is given to the teacher to find out the results of the assessment and the advice given. In the final stage, individual trials were carried out, small group trials and limited field trial trials were assessed based on aspects and indicators of assessment. The results of the assessment aspects obtained will be described as follows.

Validation of the product is intended to determine the opinions of material experts about the feasibility of content, the feasibility of presentation, and language assessment. This validation was carried out by Dr. Wisman Hadi, S.Pd., M.Hum and Dr. Pulumun Peterus Ginting, S.Sn., M.Sn. who are the Lecturer at Medan State University. The assessment was carried out to obtain information on the quality of reading material in the school literacy movement for high school students based on the local culture of Karo.

Table 1. Eligibility Criteria for Reading Materials

\begin{tabular}{|l|l|}
\hline Percentage interval & Criteria \\
\hline $81 \% \leq \mathrm{X}<100 \%$ & Very Good \\
\hline $61 \% \leq \mathrm{X}<80 \%$ & Good \\
\hline $41 \% \leq \mathrm{X}<60 \%$ & Good Enough \\
\hline $21 \% \leq \mathrm{X}<40 \%$ & Enough \\
\hline $0 \% \leq \mathrm{X}<20 \%$ & Unsatisfied \\
\hline
\end{tabular}

(Sugiyono, 2011:118)

Table 2. Score of Material Assessment by Material Experts on Feasibility of Content (Scale $1-4)$

\begin{tabular}{|c|c|c|c|}
\hline Sub Component & Indicator & Average (\%) & Criteria \\
\hline \multirow[t]{3}{*}{$\begin{array}{l}\text { A.Material } \\
\text { Accuracy }\end{array}$} & $\begin{array}{l}\text { 1. The accuracy of the concepts } \\
\text { and definitions of the text } \\
\text { contain the local culture of } \\
\text { karo land }\end{array}$ & $100 \%$ & Very Good \\
\hline & $\begin{array}{l}\text { 2. The accuracy of the concept of } \\
\text { character education values }\end{array}$ & $75 \%$ & Good \\
\hline & 3. Accuracy of terms & $87,5 \%$ & Very Good \\
\hline \multicolumn{2}{|c|}{ Average Amount of Indicators 1-3 } & $\mathbf{8 8 \%}$ & Very Good \\
\hline \multirow[t]{3}{*}{ B. Material Update } & $\begin{array}{l}\text { 4. Compatibility of material with } \\
\text { the development of science }\end{array}$ & $75 \%$ & Good \\
\hline & 5. Use stories in everyday life & $100 \%$ & Very Good \\
\hline & 6. Pictures and illustrations in & $75 \%$ & Good \\
\hline \multicolumn{2}{|c|}{ Average Amount of Indicators 4-6 } & $83 \%$ & Very Good \\
\hline
\end{tabular}




\begin{tabular}{|l|l|l|l|}
\hline $\begin{array}{l}\text { C.Encouraging } \\
\text { Curiosity }\end{array}$ & 7. Encourage curiosity & $100 \%$ & Very Good \\
\cline { 2 - 4 } & 8. Creating the ability to ask & $87,5 \%$ & Very Good \\
\hline Average Number of Indicators 7-8 & $\mathbf{9 4 \%}$ & Very Good \\
\hline The average number of all Sub Components & $\mathbf{8 8 . 3 3 \%}$ & Very Good \\
\hline
\end{tabular}

The assessment of the feasibility of presentation according to material experts was considered "very good" with an average percentage of $84 \%$. Data from the results of material expert validation on the feasibility of presentation can be seen in the following table.

Table 3. Assessment of Reading Materials by Material Experts for Feasibility of Presentation

\begin{tabular}{|c|c|c|c|}
\hline Sub Component & Indicator & $\begin{array}{l}\text { Average } \\
(\%)\end{array}$ & Criteria \\
\hline \multirow[t]{2}{*}{$\begin{array}{l}\text { A. Presentation } \\
\text { Techniques }\end{array}$} & $\begin{array}{l}\text { 1. Systematic consistency of } \\
\text { presentation }\end{array}$ & $75 \%$ & Good \\
\hline & 2. Grievance concept & $75 \%$ & Good \\
\hline \multicolumn{2}{|c|}{ Number of Indicators 1-2 } & $75 \%$ & Good \\
\hline \multirow{4}{*}{$\begin{array}{l}\text { B. Presentation of } \\
\text { Reading Materials }\end{array}$} & 3. Involvement of students & $75 \%$ & Good \\
\hline & 4. Student-centered & $75 \%$ & Good \\
\hline & $\begin{array}{l}\text { 5. Stimulating students' ability } \\
\text { to solve problems through } \\
\text { the contents of texts } \\
\text { containing the local culture } \\
\text { of Karo }\end{array}$ & $87,5 \%$ & Very Good \\
\hline & $\begin{array}{l}\text { 6. Develop emotional, social } \\
\text { and spiritual skills }\end{array}$ & $100 \%$ & Very Good \\
\hline \multicolumn{2}{|c|}{ Amount of Indicators 3-6 } & $84 \%$ & Very Good \\
\hline \multirow[t]{3}{*}{$\begin{array}{l}\text { C. Presentation } \\
\text { Completeness }\end{array}$} & $\begin{array}{l}\text { 7. Some types of local culture } \\
\text { in Karo }\end{array}$ & $100 \%$ & Very Good \\
\hline & $\begin{array}{l}\text { 8. Note of opinions / } \\
\text { experiences of students }\end{array}$ & $100 \%$ & Very Good \\
\hline & $\begin{array}{l}\text { 9. Teacher / team literacy } \\
\text { evaluation }\end{array}$ & $75 \%$ & Good \\
\hline \multicolumn{2}{|c|}{ Average Number of Indicators 7-9 } & $92 \%$ & Very Good \\
\hline \multicolumn{2}{|c|}{ Average number of Sub Components } & $84 \%$ & Very Good \\
\hline
\end{tabular}

Language assessment aspects according to material experts are considered "very good" with a total percentage of $84.60 \%$. Data on the results of material expert validation on aspects of language can be seen in the table below.

Table 4. Scores for Assessment of Reading Materials by Material Experts for Language Assessment Aspects

\begin{tabular}{|l|l|l|l|}
\hline Sub Component & Indicator & $\begin{array}{l}\text { Average } \\
(\mathbf{\%})\end{array}$ & Criteria \\
\hline A. Communicative & 1. Message readability & $87,5 \%$ & Very Good \\
\hline
\end{tabular}




\begin{tabular}{|c|c|c|c|}
\hline \multirow{2}{*}{\multicolumn{2}{|c|}{\begin{tabular}{|l|l|} 
2. Accuracy of language use \\
Number of Indicators 1-2
\end{tabular}}} & $87,5 \%$ & Very Good \\
\hline & & $87,5 \%$ & Very Good \\
\hline \multirow[t]{3}{*}{ B. Straightforward } & $\begin{array}{l}\text { 3. Accuracy of sentence } \\
\text { structure }\end{array}$ & $75 \%$ & Good \\
\hline & 4. Effectiveness of sentences & $75 \%$ & Good \\
\hline & 5. Stiffness of terms & $87,5 \%$ & Very Good \\
\hline \multicolumn{2}{|c|}{ Average Number of Indicators 3-5 } & $79 \%$ & Good \\
\hline \multirow[t]{2}{*}{$\begin{array}{l}\text { C. Dialogical and } \\
\text { interactive }\end{array}$} & $\begin{array}{l}\text { 6. The ability to motivate } \\
\text { messages or information }\end{array}$ & $75 \%$ & Good \\
\hline & $\begin{array}{l}\text { 7. The ability to encourage } \\
\text { critical thinking }\end{array}$ & $75 \%$ & Good \\
\hline \multicolumn{2}{|c|}{ Average Number of Indicators 6-7 } & $75 \%$ & Good \\
\hline \multirow{2}{*}{$\begin{array}{l}\text { D.Conformity with } \\
\text { the level of } \\
\text { development of } \\
\text { students }\end{array}$} & $\begin{array}{l}\text { 8. Conformity of students' } \\
\text { intellectual development }\end{array}$ & $87,5 \%$ & Very Good \\
\hline & $\begin{array}{l}\text { 9. Conformity with the level of } \\
\text { emotional development of } \\
\text { students }\end{array}$ & $87,5 \%$ & Very Good \\
\hline \multicolumn{2}{|c|}{ Average Number of Indicators 8-9 } & $87,5 \%$ & Very Good \\
\hline \multirow{2}{*}{$\begin{array}{l}\text { E. Use of terms, } \\
\text { symbols and } \\
\text { icons }\end{array}$} & $\begin{array}{l}\text { 10. Consistency in the use of } \\
\text { terms }\end{array}$ & $100 \%$ & Very Good \\
\hline & $\begin{array}{l}\text { 11. consistency in the use of } \\
\text { symbols or icons }\end{array}$ & $87,5 \%$ & Very Good \\
\hline \multicolumn{2}{|c|}{ Average Number of Indicators 10-11 } & $94 \%$ & Very Good \\
\hline \multicolumn{2}{|c|}{ Average Number of Overall Sub Components } & $84.60 \%$ & Very Good \\
\hline
\end{tabular}

Table 5. Percentage of Assessment from Material Experts on Content Feasibility

\begin{tabular}{|l|l|l|l|}
\hline No & Sub Component of Assessment & Average (\%) & Criteria \\
\hline 1 & Material accuracy & $88 \%$ & Very Good \\
\hline 2 & Material update & $83 \%$ & Very Good \\
\hline 3 & Encourage curiosity & $94 \%$ & Very Good \\
\hline Average & $\mathbf{8 8 . 3 3 \%}$ & Very Good \\
\hline
\end{tabular}

Table 6. Percentage of Assessment by Material Experts on Feasibility of Presentation

\begin{tabular}{|l|l|l|l|}
\hline No & Sub Component of Assessment & $\begin{array}{l}\text { Average } \\
(\mathbf{\%})\end{array}$ & Criteria \\
\hline 1 & Presentation technique & $75 \%$ & Good \\
\hline 2 & Presentation of reading material & $84 \%$ & Very Good \\
\hline 3 & Complete presentation & $92 \%$ & Very Good \\
\hline Average & $\mathbf{8 4 \%}$ & Very Good \\
\hline
\end{tabular}


Table 7 Percentage of Assessment by Material Experts on Language Assessment

\begin{tabular}{|l|l|l|l|}
\hline No & Sub Component of Assessment & $\begin{array}{l}\text { Average } \\
(\mathbf{\%})\end{array}$ & Criteria \\
\hline 1 & Communicative & $87,5 \%$ & Very Good \\
\hline 2 & Straightforward & $79 \%$ & Good \\
\hline 3 & Dialogue and Interactive & $75 \%$ & Good \\
\hline 4 & $\begin{array}{l}\text { Conformity with the level of } \\
\text { development of students }\end{array}$ & $87,5 \%$ & Very Good \\
\hline 6 & Use of terms, symbols and icons & $94 \%$ & Very Good \\
\hline Average & $\mathbf{8 4 . 6 0 \%}$ & Very Good \\
\hline
\end{tabular}

An expert validator who validates the design of reading material in the school literacy movement for high school students based on the local culture of Tanah Karo is Dr. Evi Eviyanti, M.Pd., and Dr. Mursid, S.T., M.Pd., who are the lecturer at Medan State University. The assessment of the reading material design was carried out to improve the quality of the reading material developed. The results of the validation of the reading material by the design experts concluded that the reading material developed was in the criteria of "very good" with a total average percentage of $84.75 \%$. Data from the validation of reading material design experts can be seen in the table below.

Table 8. Assessment Score Material Design Scores

\begin{tabular}{|c|c|c|c|}
\hline Component & Indicator & $\begin{array}{l}\text { Average } \\
(\%)\end{array}$ & Criteria \\
\hline \multirow{2}{*}{$\begin{array}{l}\text { A. Size of } \\
\text { Reading } \\
\text { Materia } \\
\text { l }\end{array}$} & $\begin{array}{l}\text { 1. Suitability of reading material sizes with } \\
\text { ISO standards (A4, A5, and B5) }\end{array}$ & $87,5 \%$ & Very Good \\
\hline & $\begin{array}{l}\text { 2. Appropriateness of the size of the material } \\
\text { contained in the reading material }\end{array}$ & $75 \%$ & Good \\
\hline \multicolumn{2}{|c|}{ Number of Indicators 1-2 } & $\mathbf{8 1 , 2 5 \%}$ & Very Good \\
\hline \multirow{5}{*}{$\begin{array}{l}\text { B. Reading } \\
\text { Materia } \\
1 \text { Cover } \\
\text { Design } \\
\text { (Cover) }\end{array}$} & $\begin{array}{l}\text { 3. Appearance of the layout elements on the } \\
\text { front, back and back covers harmoniously } \\
\text { has a rhythm and unity and is consistent. }\end{array}$ & $75 \%$ & Good \\
\hline & 4. Display a good center point. & $87,5 \%$ & Very Good \\
\hline & $\begin{array}{l}\text { 5. The color elements of the layout are } \\
\text { harmonious and clarify the function. }\end{array}$ & $100 \%$ & Very Good \\
\hline & $\begin{array}{l}\text { 6. The composition and size of the layout } \\
\text { elements (title, author, illustration, logo, } \\
\text { etc.) are proportional, balanced, and in line } \\
\text { with the content layout (according to the } \\
\text { pattern). }\end{array}$ & $75 \%$ & Good \\
\hline & $\begin{array}{l}\text { 7. The font size of the book title is more } \\
\text { dominant and proportional than the size of } \\
\text { the reading material, the name of the } \\
\text { author. }\end{array}$ & $87,5 \%$ & Very Good \\
\hline
\end{tabular}




\begin{tabular}{|c|c|c|c|}
\hline & $\begin{array}{l}\text { 8. The color of the book's title contrasts with } \\
\text { the background color. }\end{array}$ & $75 \%$ & Good \\
\hline & 9. Do not use too many font combinations. & $87,5 \%$ & Very Good \\
\hline & $\begin{array}{l}\text { 10. Describe the contents and express the } \\
\text { character of the object. }\end{array}$ & $87,5 \%$ & Very Good \\
\hline & $\begin{array}{l}\text { 11. Shape, color, size, proportion of objects } \\
\text { according to reality. }\end{array}$ & $87,5 \%$ & Very Good \\
\hline Average Am & ount of Indicators 3-11 & $85 \%$ & Very Good \\
\hline & $\begin{array}{l}\text { 12. Layout element layout is consistent based } \\
\text { on patterns }\end{array}$ & $75 \%$ & Good \\
\hline & 13. Separation between paragraphs is clear & $100 \%$ & Very Good \\
\hline & 14. Printing area and proportional margin & $87,5 \%$ & Very Good \\
\hline & $\begin{array}{l}\text { 15. The two-page margin is side by side } \\
\text { proportional }\end{array}$ & $87,5 \%$ & Very Good \\
\hline & $\begin{array}{l}\text { 16. Spaces between text and illustrations are } \\
\text { appropriate }\end{array}$ & $75 \%$ & Good \\
\hline & $\begin{array}{l}\text { 17. The placement of illustrations and } \\
\text { captions is appropriate }\end{array}$ & $100 \%$ & Very Good \\
\hline & $\begin{array}{l}\text { 18. Placement of decoration / illustration as } \\
\text { background does not interfere with title, } \\
\text { text, page numbers. }\end{array}$ & $75 \%$ & Good \\
\hline & $\begin{array}{l}\text { 19. The placement of titles, subtitles, } \\
\text { illustrations, and captions does not } \\
\text { interfere with understanding. }\end{array}$ & $87,5 \%$ & Very Good \\
\hline & $\begin{array}{l}\text { 20. The use of letter variations (bold, italic, } \\
\text { all capital, small capital) is not excessive. }\end{array}$ & $100 \%$ & Very Good \\
\hline & 21. Normal text width. & $87,5 \%$ & Very Good \\
\hline & 22. Normal text line spacing. & $75 \%$ & Good \\
\hline & 23. Normal kerning space. & $87,5 \%$ & Very Good \\
\hline & $\begin{array}{l}\text { 24. The hierarchy of titles is clear, consistent } \\
\text { and proportional. }\end{array}$ & $87,5 \%$ & Very Good \\
\hline & 25. Sign of cutting words (hyphenation). & $87,5 \%$ & Very Good \\
\hline & $\begin{array}{l}\text { 26. Able to reveal the meaning / meaning of } \\
\text { the object. }\end{array}$ & $100 \%$ & Very Good \\
\hline & $\begin{array}{l}\text { 27. Accurate and proportional forms in } \\
\text { accordance with reality. }\end{array}$ & $87,5 \%$ & Very Good \\
\hline & 28. Creative and dynamic & $87,5 \%$ & Very Good \\
\hline Average Nui & nber of Indicators 12-28 & $\mathbf{8 8 \%}$ & Very Good \\
\hline Average Ove & rall Amount & $84.75 \%$ & Very Good \\
\hline
\end{tabular}

Table 9. Percentage of Assessment from Designers

\begin{tabular}{|l|l|l|l|}
\hline No & Sub Component of Assessment & Average (\%) & Criteria \\
\hline 1 & Size of reading material & $81,25 \%$ & Very Good \\
\hline 2 & Design of cover material & $85 \%$ & Very Good \\
\hline
\end{tabular}




\begin{tabular}{|l|l|l|l|}
\hline 3 & $\begin{array}{l}\text { Design the contents of the reading } \\
\text { material }\end{array}$ & $88 \%$ & Very Good \\
\hline Average & $\mathbf{8 4 . 7 5 \%}$ & Very Good \\
\hline
\end{tabular}

\subsection{Use of Reading Materials Based on Karo Local Culture}

The use of reading material in the school literacy movement for high school students based on the local culture of Karo was obtained from the results of the assessment of responses or perceptions given by two Indonesian language teachers and 32 students of senior high school 1 Berastagi. Each aspect of the overall assessment is determined by the average score of the teacher / student respondent's indicators / statements. Through the results of the assessment, it was then analyzed to determine the use of reading material in the school literacy movement for high school students based on the local culture of Karo. The results of the assessment aspects obtained based on the results of teacher and student responses to reading material in the school literacy movement will be described as follows.

Table 10. Data on Indonesian Language Teacher Assessment of Reading Materials

\begin{tabular}{|c|c|c|c|c|c|c|}
\hline \multirow{2}{*}{ No } & \multirow{2}{*}{ Indicator/Statement } & \multicolumn{2}{|c|}{ Respondent } & \multirow{2}{*}{$\begin{array}{l}\text { Total } \\
\text { Score }\end{array}$} & \multirow{2}{*}{ Average } & \multirow{2}{*}{ Criteria } \\
\hline & & 1 & 2 & & & \\
\hline 1 & $\begin{array}{l}\text { The overall reading material looks } \\
\text { interesting }\end{array}$ & 4 & 3 & 7 & $87,5 \%$ & Very Good \\
\hline 2 & $\begin{array}{l}\text { The language used in reading } \\
\text { material is easy to understand }\end{array}$ & 4 & 4 & 8 & $100 \%$ & Very Good \\
\hline 3 & $\begin{array}{l}\text { The presentation of the text in the } \\
\text { reading material is well arranged }\end{array}$ & 3 & 4 & 7 & $87,5 \%$ & Very Good \\
\hline 4 & $\begin{array}{l}\text { Use of images in clear reading } \\
\text { material }\end{array}$ & 3 & 3 & 6 & $75 \%$ & Good \\
\hline 5 & $\begin{array}{l}\text { The text content in reading } \\
\text { material stimulates } \\
\text { thinking skills }\end{array}$ & 4 & 3 & 7 & $87,5 \%$ & Very Good \\
\hline 6 & $\begin{array}{l}\text { The reading material contains the } \\
\text { local wisdom of Karo culture }\end{array}$ & 4 & 4 & 8 & $100 \%$ & Very Good \\
\hline 7 & $\begin{array}{l}\text { Reading material can be used as } \\
\text { material for the School Literacy } \\
\text { Movement }\end{array}$ & 3 & 4 & 7 & $87,5 \%$ & Very Good \\
\hline 8 & $\begin{array}{l}\text { Fill text reading material } \\
\text { according to student development }\end{array}$ & 3 & 3 & 6 & $75 \%$ & Good \\
\hline 9 & $\begin{array}{l}\text { Reading material makes it easy for } \\
\text { students to express their opinions } \\
\text { in oral and written form }\end{array}$ & 4 & 3 & 7 & $87,5 \%$ & Very Good \\
\hline 10 & $\begin{array}{l}\text { Use of symbols in accordance with } \\
\text { existing rules }\end{array}$ & 3 & 4 & 7 & $87,5 \%$ & Very Good \\
\hline 11 & $\begin{array}{l}\text { This reading is different from the } \\
\text { usual reading material }\end{array}$ & 4 & 4 & 8 & $100 \%$ & Very Good \\
\hline
\end{tabular}




\begin{tabular}{|l|l|l|l|l|l|l|}
12 & $\begin{array}{l}\text { Reading materials train students to } \\
\text { enrich students' knowledge and } \\
\text { personality }\end{array}$ & 4 & 4 & 8 & $100 \%$ & Very Good \\
\hline 13 & $\begin{array}{l}\text { Reading material can be studied } \\
\text { independently by students }\end{array}$ & 4 & 4 & 8 & $100 \%$ & Very Good \\
\hline 14 & $\begin{array}{l}\text { Reading material helps students } \\
\text { understand it within 15 minutes }\end{array}$ & 3 & 4 & 7 & $87,5 \%$ & Very Good \\
\hline & Average Amount & $\mathbf{5 0}$ & $\mathbf{5 1}$ & $\mathbf{1 0 1}$ & $\mathbf{9 0 , 1 8 \%}$ & Very Good \\
\hline
\end{tabular}

The results of the teacher's response to reading material in the school literacy movement for high school students based on the local culture of Karo developed had an average percentage of $90.18 \%$ with the criteria of "very good". This means that the reading material that has been developed can meet the demands of the school literacy movement for high school students based on the local culture of Karo which is the culture of the students themselves in senior high school 1 Berastagi

The stage of testing the reading material through 3 trial processes, namely: 1) individual trials, 2) small group trials, and 3) limited field trials. The results of the trials carried out can be described as follows.

1) Student Test Results on Reading Materials in Individual Trials

Table 11. Individual Trial Data (3 students) on Reading Materials

\begin{tabular}{|c|c|c|c|c|c|c|c|}
\hline \multirow{2}{*}{ No } & \multirow{2}{*}{ Indicator/Statement } & \multicolumn{3}{|c|}{ Respondent } & \multirow{2}{*}{$\begin{array}{l}\text { Total } \\
\text { Score }\end{array}$} & \multirow{2}{*}{ Average } & \multirow{2}{*}{ Criteria } \\
\hline & & 1 & 2 & 3 & & & \\
\hline 1 & $\begin{array}{l}\text { These reading materials motivate } \\
\text { me to study }\end{array}$ & 3 & 3 & 3 & 9 & $75 \%$ & Good \\
\hline 2 & $\begin{array}{l}\text { I can understand the text presented } \\
\text { easily and read in } 15 \text { minutes }\end{array}$ & 3 & 4 & 3 & 10 & $83,33 \%$ & Very Good \\
\hline 3 & $\begin{array}{l}\text { I like reading the Karo cultural } \\
\text { content text in this reading material } \\
\text { because it can add to my insight } \\
\text { into Karo culture }\end{array}$ & 4 & 3 & 4 & 11 & $91,66 \%$ & Very Good \\
\hline 4 & $\begin{array}{l}\text { The presentation of Karo cultural } \\
\text { content texts in this reading } \\
\text { material encouraged me to discuss } \\
\text { with other friends }\end{array}$ & 3 & 3 & 3 & 9 & $75 \%$ & Good \\
\hline 5 & $\begin{array}{l}\text { This reading contains questions } \\
\text { that encourage me to think } \\
\text { critically }\end{array}$ & 3 & 3 & 4 & 10 & $83,33 \%$ & Very Good \\
\hline 6 & $\begin{array}{l}\text { This reading material contains the } \\
\text { value of local wisdom that I can set } \\
\text { an example in life }\end{array}$ & 3 & 3 & 2 & 8 & $66,66 \%$ & Good \\
\hline 7 & $\begin{array}{l}\text { The language used is simple and } \\
\text { easy to understand }\end{array}$ & 3 & 2 & 3 & 8 & $66,66 \%$ & Good \\
\hline
\end{tabular}




\begin{tabular}{|l|l|l|l|l|l|l|l|}
8 & $\begin{array}{l}\text { I can read the text on this reading } \\
\text { material easily because the type of } \\
\text { font size chosen is right }\end{array}$ & 3 & 3 & 3 & 9 & $75 \%$ & Good \\
\hline 9 & $\begin{array}{l}\text { This reading encourages my desire } \\
\text { to love reading and writing }\end{array}$ & 3 & 2 & 3 & 8 & $66,66 \%$ & Good \\
\hline 10 & $\begin{array}{l}\text { My reading comprehension has } \\
\text { increased when I read this reading } \\
\text { material }\end{array}$ & 3 & 3 & 3 & 9 & $75 \%$ & Good \\
\hline
\end{tabular}

The results of the assessment of individual trials above concluded that the reading material developed was included in the criteria of "good" with a total average percentage of $76 \%$. Individual trials were carried out to determine students' initial responses and to identify product shortages of products developed before small group trials were conducted.

Table 12 Student Trial Data from Small Group Trials (9 students) on Reading Materials

\begin{tabular}{|c|c|c|c|}
\hline No & Indicator/Statement & Average & Criteria \\
\hline 1 & $\begin{array}{l}\text { These reading materials motivate me to } \\
\text { study }\end{array}$ & $80,55 \%$ & Very Good \\
\hline 2 & $\begin{array}{l}\text { I can understand the text presented easily } \\
\text { and read in } 15 \text { minutes }\end{array}$ & $80,55 \%$ & Very Good \\
\hline 3 & $\begin{array}{l}\text { I like reading the Karo cultural content text } \\
\text { in this reading material because it can add to } \\
\text { my insight into Karo culture }\end{array}$ & $83,33 \%$ & Very Good \\
\hline 4 & $\begin{array}{l}\text { The presentation of Karo cultural content } \\
\text { texts in this reading material encouraged me } \\
\text { to discuss with other friends }\end{array}$ & $83,33 \%$ & Very Good \\
\hline 5 & $\begin{array}{l}\text { This reading contains questions that } \\
\text { encourage me to think critically }\end{array}$ & $83,33 \%$ & Very Good \\
\hline 6 & $\begin{array}{l}\text { This reading material contains the value of } \\
\text { local wisdom that I can set an example in life }\end{array}$ & $86,11 \%$ & Very Good \\
\hline 7 & $\begin{array}{l}\text { The language used is simple and easy to } \\
\text { understand }\end{array}$ & $83,33 \%$ & Very Good \\
\hline 8 & $\begin{array}{l}\text { I can read the text on this reading material } \\
\text { easily because the type of font size chosen is } \\
\text { right }\end{array}$ & $83,33 \%$ & Very Good \\
\hline 9 & $\begin{array}{l}\text { This reading encourages my desire to love } \\
\text { reading and writing }\end{array}$ & $83,33 \%$ & Very Good \\
\hline 10 & $\begin{array}{l}\text { My reading comprehension has increased } \\
\text { when I read this reading material }\end{array}$ & $86,11 \%$ & Very Good \\
\hline \multicolumn{2}{|c|}{ Average Amount } & $83,33 \%$ & Very Good \\
\hline
\end{tabular}


The results of a small group trial about students' perceptions of reading material in the school literacy movement for high school students based on the local culture of Karo that had been developed showed an average percentage of $83.33 \%$ with the criteria of "very good". These results are obtained after an improvement or revision of individual trials so that the reading material is revised back from the material arrangement and the use of language that is easier for students to understand.

Table 13. Student Trial Data from Limited Field Trials (32 students) on Reading Materials

\begin{tabular}{|c|c|c|c|}
\hline No & Indicator/Statement & Average & Criteria \\
\hline 1 & These reading materials motivate me to study & $86,72 \%$ & Very Good \\
\hline 2 & $\begin{array}{l}\text { I can understand the text presented easily and } \\
\text { read in } 15 \text { minutes }\end{array}$ & $90,63 \%$ & Very Good \\
\hline 3 & $\begin{array}{l}\text { I like reading the Karo cultural content text in } \\
\text { this reading material because it can add to my } \\
\text { insight into Karo culture }\end{array}$ & $91,41 \%$ & Very Good \\
\hline 4 & $\begin{array}{l}\text { The presentation of Karo cultural content } \\
\text { texts in this reading material encouraged me } \\
\text { to discuss with other friends }\end{array}$ & $89,06 \%$ & Very Good \\
\hline 5 & $\begin{array}{l}\text { This reading contains questions that } \\
\text { encourage me to think critically }\end{array}$ & $89,06 \%$ & Very Good \\
\hline 6 & $\begin{array}{l}\text { This reading material contains the value of } \\
\text { local wisdom that I can set an example in life }\end{array}$ & $90,63 \%$ & Very Good \\
\hline 7 & $\begin{array}{l}\text { The language used is simple and easy to } \\
\text { understand }\end{array}$ & $89,06 \%$ & Very Good \\
\hline 8 & $\begin{array}{l}\text { I can read the text on this reading material } \\
\text { easily because the type of font size chosen is } \\
\text { right }\end{array}$ & $89,84 \%$ & Very Good \\
\hline 9 & $\begin{array}{l}\text { This reading encourages my desire to love } \\
\text { reading and writing }\end{array}$ & $91,41 \%$ & Very Good \\
\hline 10 & $\begin{array}{l}\text { My reading comprehension has increased } \\
\text { when I read this reading material }\end{array}$ & $90,63 \%$ & Very Good \\
\hline \multicolumn{2}{|c|}{ Average Amount } & $89,84 \%$ & Very Good \\
\hline
\end{tabular}




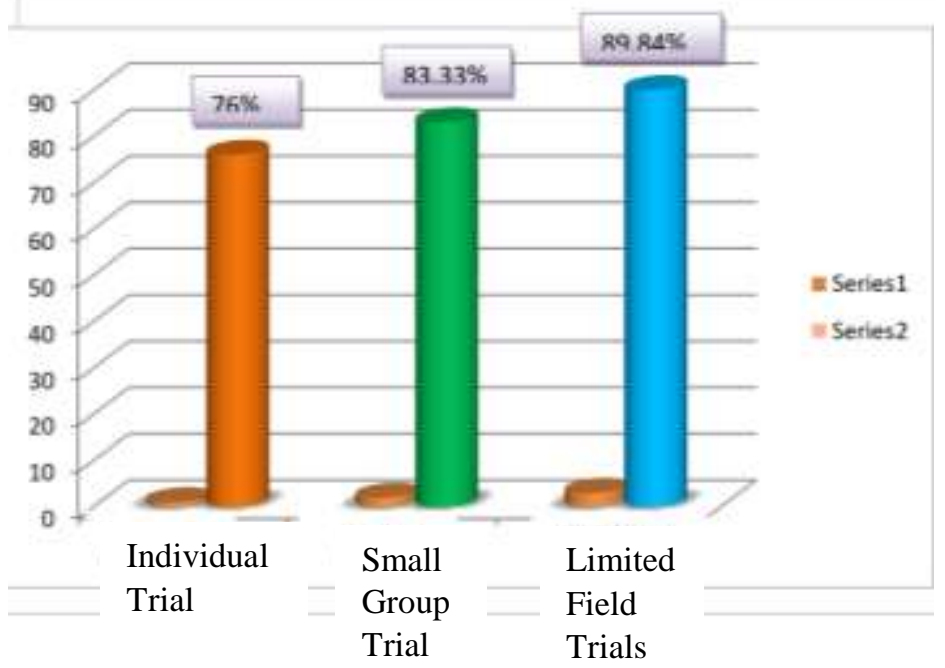

Figure 9. Comparison of Student Assessments on Individual, Small Group and Limited Field Trials

Based on the picture above diagram can be seen the comparison of the results of individual, small group, and limited field trials. The percentage of students' perceptions on individual trials of reading material in the school literacy movement for high school students based on the developed local culture of Karo shows an average percentage of $76 \%$ with the criteria of "good". Students' perceptions of small group trials showed an average percentage of $83.33 \%$ with the criteria of "very good". Students' perceptions of limited field trials show an average percentage of $89.84 \%$ with the criteria of "very good". It was concluded that the results of the trials always increase at each stage. This means that the use of reading material in the school literacy movement for high school students based on the local culture of Karo is very effective.

\section{Conclusion}

The development of reading material is based on research and preliminary information gathering, planning, initial product development, material content validation and design, product revision, assessment and advice of language teachers and students, revisions, individual trials, revisions, small group trials, revisions, trials limited field, revisions to valid and feasible products.

The feasibility of reading material in the school literacy movement for high school students based on local culture in Karo is eligible and worth to be used as reading material, based on the assessment of material experts, and design experts. The results of the material expert validation included the eligibility of content with an average of $88.33 \%$ on the criteria of "very good", the feasibility of presentation with an average of $84 \%$ on the criteria of "very good", aspects of language with an average of $84.60 \%$ on the criteria of "very good", the average overall aspect is $85.64 \%$ on the criteria of "very good", and the validation of design experts with an average of $84.75 \%$ on the criteria of "very good".

The use of reading material in the school literacy movement for senior high school students based on the local culture of Karo fulfills the requirements and is effectively used as a reading material. The results of the teacher's response to reading material in the school literacy movement for senior high school students based on the local culture of Karo developed 
have an average percentage of $90.18 \%$ with the criteria of "very good". The results of the average percentage of the overall limited field test are $89.84 \%$ with the criteria of "very good". The results of the assessment based on the responses of teachers and students in the Senior High School 1 of Berastagi concluded that reading material in the school literacy movement for senior high school students based on local culture of Tanah Karo had been found to be effective because it met the needs and overall criteria of "very good".

\section{References}

A. Sayuti S. 2009. Teks Sastra Bandung. Yogyakarya: Universitas Negeri Yogyakarta Ali Ridwan, Nurma. 2007. Landasan Keilmuan Kearifan Lokal. STAIN Purwokerto.

Borg and Gall. 1983. Educational Research, An Introduction. New York and London. Longman Inc

Cladwell, J. S. (2008). Comprehension assessment: A classroom guide. New York: The Guilford Press

Daryanto, Hery Tarno. 2015. Pengelolaan Budaya dan Iklim Sekolah. Yogyakarta: Gava Media

Farida Rahim. 2008. Pengajaran Membaca di Sekolah. Jakarta: Bumi Aksara

Gardiner, Steve. 2005. Building student literacy through sustained silent reading.USA: ASCD.

Gay, L.R. 1990. Educational Evaluation and Measurement: Com-petencies for Analysis and Application. Second Edition. New York: Macmillan University press

Geerts, Clifford. 2004. Local Knowlegde and It's Limit. Yale: Johns Hopkins University Press

Gong, A, Gol, Agus M Irkham. 2012. Gempa Literasi: Dari Kampung untuk Nusantara. Jakarta: Kepustakaan Populer Gramedia

Kemendikbud. 2013. Bahasa Indonesia Ekspresi Diri dan Akademik: Buku Guru. Jakarta: kemendikbud

Kemendikbud. 2016. Panduan Gerakan Literasi Sekolah di Sekolah Menengah Atas. Jakarta: Kemendikbud

Koesoema, A Doni. 2007. Pendidikan Karakter, Strategi Mendidik Anak di Zaman Global. Jakarta: Grasindo

Kosasih, E. 2014. Jenis-Jenis Teks. Bandung: Yrama Widya

Lipton Laura, Deborah Hubble. 2016. Sekolah Literasi Perencanaan \& Pembinaan. Bandung: Nuansa Cendikia

Makmur, Syarif. 2008. Pemberdayaan sumber daya manusia dan efektivitas organisasi : Kajian penyelenggaraan pemerintahan desa. Jakarta: Raja Grafindo Persada.

Mulyani, Yoyo. 2011. Keefektifan Model Pembelajaran Estetika Resepsi dalam Pembelajaran Kajian Puisi. Disertasi

Nuriadi. 2008. Teknik Jitu Menjadi Pembaca Terampil. Yogyakarta: Pustaka Pelajar

Prastowo, Andi. 2012. Panduan Kreatif Membuat Bahan Ajar Inovatif. Jogjakarta: DIV A Press

Sartini. 2006. Menggali Kearifan Lokal Nusantara Sebuah Kajian Filsafati, http://filsafat.ugm.co.id, Accessed on 30 April 2017.

Somadoyo, Samsu. 2011. Strategi dan Tehnik Pembelajaran Membaca. Yogyakarta: Graha Ilmu.

Subyantoro. 2011. Pengembangan Keterampilan Membaca Cepat. Yogyakarta: Graha Ilmu. Sugiyono. 2014. Metode Penelitian Kuantitatif, Kualitatif dan R\&D. Bandung: Alfabeta 
www.bircu-journal.com/index.php/birle emails: birle.journal@gmail.com birle.journal.qa@gmail.com

Tarigan Henry Guntur. 2008. Membaca Sebagai Suatu Keterampilan Berbahasa. Bandung: Angkasa.

Van den Akker J. 1999. Principles and Methods od Development Research. Pada J. Van Den Akker, R. Branch, K. Gustafson, Nieven, dan T. Plomp (eds), Design Approaches and Tools in Education and Training (pp. 1-14) Dortrech: Kluwer Academic Publishers

Yulia, Yuyu and Janti Gristinawati Sujana. 2009. Pengembangan Koleksi. Jakarta: Universitas Terbuka. 